\title{
Main Dimensions in the Building of the Circular Supply Chain: A Literature Review
}

\author{
Rocío González-Sánchez ${ }^{1, *(\mathbb{D}}$, Davide Settembre-Blundo ${ }^{1,2}{ }^{\mathbb{D}}$, Anna Maria Ferrari ${ }^{3}$ and \\ Fernando E. García-Muiña ${ }^{1}$ (D) \\ 1 Department of Business Administration (ADO), Applied Economics II and Fundaments of Economic \\ Analysis, Rey-Juan-Carlos University, 28032 Madrid, Spain; davide.settembre@gresmalt.it (D.S.-B.); \\ fernando.muina@urjc.es (F.E.G.-M.) \\ 2 Gruppo Ceramiche Gresmalt, Via Mosca 4, 41049 Sassuolo, Italy \\ 3 Department of Sciences and Methods for Engineering, University of Modena and Reggio Emilia, \\ 42122 Reggio Emilia, Italy; annamaria.ferrari@unimore.it \\ * Correspondence: rocio.gonzalez@urjc.es; Tel.: +34-91-4887-786
}

Received: 29 February 2020; Accepted: 15 March 2020; Published: 20 March 2020

\begin{abstract}
Circular economy is an alternative to the traditional production model and has therefore attracted a great deal of attention from researchers. The change in the production system is accompanied by new logistical needs related both to resources and waste and to the distribution and recovery of products. The circular supply chain involves return processes and the manufacturer intends to capture additional value in the supply chain. In this paper, value chains have been mapped to visualize the links and interactions between the different stages and actors to understand the complexities of these systems and to make informed decisions. For this reason, and based on thorough literature review, the final objective of this work is to achieve a conceptual framework to study circular supply chain, which uses the main theoretical perspectives in strategic management literature. Four dimensions have been identified to support the development of these new supply chains-greater intensity in the relationships established in the supply chain, adaptation of logistics and organizational, disruptive and smart technologies, and a functioning environment. It can be concluded that to develop a new relationship capacity will allow for reaching more frequent, closer relationships with more actors. These relationships will be developed within an adapted organizational and logistical framework that is framed in new business model archetypes. However, dimensions related to the business environment such as sectoral, legislative, and fiscal frameworks must be incorporated.
\end{abstract}

Keywords: circular supply chain (CSC); circular supply chain management (CSCM); circular economy; sustainability; literature review; value creation

\section{Introduction}

The requirement to cover a constantly growing globalized demand in a sustainable way, implies an adequate and efficient management of supply chain operations [1]. Certain sectors, such as the automotive industry, have a complex supply chain network responsible for much of the environmental degradation in their value chain [2]. Concerned with improving sustainability in their supply chains to enhance their operational, economic, and social responsibility performance, many companies have begun to incorporate new or recycled materials, cleaner technologies, and new organizational and logistical practices $[3,4]$.

Numerous papers support the importance of effective supply chain management for the economy of many countries. The development of policies and actions that achieve a more efficient and sustainable supply chain will allow better results, through the design of cost-efficient schedules, facilitating the 
flow, supporting "just-in-time" deliveries within supply chains, adopting 3R (reduce/reuse/recycle), and improving sustainability of the operations [3,5]. Management of the total cost in the supply chain must consider aspects such as transport costs, penalties for delays, costs for emissions, etc. Many of these costs not only have an impact on the profit and loss account, but also affect the sustainability of the supply process [6,7]. In fact, to facilitate processes within supply chains, reducing associated delays and improving the sustainability of supply chain operations, many distribution companies began to apply new systems and new techniques, as the dual-channel supply chains in which the manufacturer uses both vertical integration online and an offline intermediary [7], or the cross-docking technique that provides the fast flow of products from inbound trucks to assigned outbound trucks $[1,3]$.

Integration and cooperation between production operations and transport enables improved performance and sustainability in the supply chain [6]. Sustainability need be reached through the network of corporation. This implies the involvement and coordination of the different actors of the supply chain, including manufacturers, logistics companies, distribution facility operators, and retailers [3,7]. Consequently, it is important to consider behavior at both the individual and organizational level. It is recommended that a strong mechanism be designed to motivate all members of the supply chain to participate in a joint sustainability effort that incorporates several types of perspectives [4]. So, [7] propose a sustainable risk-sharing contract which could distribute profits between channel members and coordinate the system under a fixed risk-sharing degree.

"The holistic shift from traditional supply chain to sustainable supply chain has been practiced in different industries for many years" [2] (p. 1). However, the application of the principles of the circular economy to the functioning of the supply chain, requires organizations to redesign their chains under a new approach [8]. The circular economy (CE) is an alternative paradigm to the current and dominant production model called "take-make-waste-dispose" [9-12] that causes a high amount of waste and an inability to regenerate the resources used. Therefore, $\mathrm{CE}$ can be considered an attempt to respond to a productive system based on the incessant development of economies of scale that will enable a continuous and growing demand for new products and services to be satisfied. Accordingly, through a programmed obsolescence [13], the life cycle of products launched on the market is reduced, which leads us to a "society based on waste".

In opposition, the CE would consider transforming the models of production and consumption oriented towards products, to models oriented towards solutions. Along these lines, various studies reconsider the management of materials and products or services, experimenting with how to extend their useful life, reuse them, re-manufacture or recycle them along the value chain from cradle to cradle [14-17]. It would imply a reduction in the production and consumption of raw materials [18]. Consequently, circular supply chain (CSC) promotes transformation from a linear to a circular model of flow of products [19]. The aim would be to provide a coherent framework for redesigning systems to enable a restorative economy, based on a benefit from the flow of resources and products over their lifetime, limiting the material input to society [20-22]. Thus, environmental management positively influences operational performance [23]. Change in the production system is accompanied by new logistical needs related both to resources and waste and to the distribution and recovery of products. Thus, the network of organizations involved in the supply chain establishes upward and downward linkages in the different processes and activities, so it is necessary to achieve a necessary integration [24]. The CSC involves "return processes and the manufacturer intends to capture additional value and further integrate all activities in the supply chain" [25] (p. 3).

The possibility of achieving a more sustainable economic system has attracted the attention of both researchers and other stakeholders, which has been reflected in a significant increase in articles published in recent years in international journals indexed in the top positions of recognized databases [26]. However, research on supply chain development in the field of circular economy is fragmented between several research streams [26,27]. Although the field of supply chain research is well established, further research is needed on the adaptation of the chain to the principles of circular economy [28,29]. This paper conducts a systematic literature review (SLR) on the CSCs. However, 
there are still numerous areas of research that require further study $[15,16]$, which could be gathered around two fundamental pillars-their conceptualization and implantation [30].

Circular supply chain has become a strategic variable for organizations, going beyond environmental aspects. There is also an important route widening the focus of study and considering the social and economic scenarios that affect the different stakeholders, in a broad sense [31], as most of the research on practices in the sphere of change towards a more sustainable productive system has been developed [16]. It is necessary to define a new range of specific actions to adequately implement the circular economy principles to supply chains, for which the adoption of systemic innovations is necessary.

To achieve these goals, the present research addresses the following main research questions:

1. What is the definition of circular supply chain? What other terms are used as synonyms and what differential aspects can be established?

2. What theories of strategic management could be applied to the analysis of the circular supply chain that would make it easier to frame the practices to be carried out?

3. What are the dimensions that allow the design of circular supply chains? What kind of challenges do they pose?

The paper is structured as follows. After this introduction, the paper presents a description of the methodology used to select previous literature and a brief definition of the circular supply chain. Next, fundamental criteria to consider when designing specific actions in the design and implementation of supply chains. Finally, findings, conclusions, and future lines of research are presented.

\section{Materials and Methods}

To understand a phenomenon, it is necessary to build a theoretical basis. Similarly, to innovate and create new possibilities to empirically reconstruct phenomena, it is also necessary to go beyond the current theoretical frameworks [32]. The building of a theory is a slow and progressive process of construction. The first contributions are not very specific, but as it is studied in depth, the theoretical framework establishes the dimensions that give it its identity. A systematic review of the literature has been carried out as it allows for the evaluation and interpretation of all available research that is relevant to a particular research question in a thematic area. It is a suitable method for structuring the conceptual basis of the novel research topic [33]. Building a correct theoretical base allows the development of useful action models. It allows us to summarize the existing evidence, and therefore, to capture the existing knowledge for its development. In addition, through this type of review some gaps in current research can be identified to define future areas of research.

Systematic review of the literature is a form of secondary study that uses a well-defined methodology. For this, the next step is to define the search protocol, the terms to be searched, the combinations of terms, the search strategy used for each source and how the results of each search will be recorded. The phases of this research begin with the formulation of the research questions, after which the articles were located in the databases with the highest coverage for the researched topic: Scopus. The literature review was conducted between November 2019 and February 2020. The keywords used in the search were "circular supply chain"; "green supply chain" AND "circular economy"; and "closed-loop supply chain" AND "circular economy", according to the following steps. The first search was made through the main term-"circular supply chain"-in the title, abstract, keywords, and the main text of the papers. This first search was completed with the terms associated-green supply chain and closed-loop supply chain-when the article is associated to the $\mathrm{CE}$, if the journal has no results from the first search or only one paper. Limiting the literature search to the one in which authors choose to explicitly mention CE, ensures that only relevant content has been included [34]. To corroborate the suitability of the selected papers, in a second round, the theoretical development of the paper was analyzed in detail. 
Based on Ferreira Gregorio, Pié, and Terceño's study [35], we considered the main journals with the highest impact on Scopus-Q1 and Q2 - with the greatest number of papers published on circular economy. The six main journals with the greatest impact in the categories directly related to the analyzed concept were used in the search (Journal of Cleaner Production; Sustainability; Resources, Conservation and Recycling; Production Planning and Control; Journal of Industrial and Production Engineering; and Ecological Economics). In two of them no results were found-Journal of Industrial and Production Engineering and Ecological Economics - and new two of great impact were incorporated-Production Planning and Control; and Resources (Table 1).

Table 1. Sources of information.

\begin{tabular}{|c|c|c|c|}
\hline Journal & $\begin{array}{l}\text { Number of } \\
\text { Documents }\end{array}$ & $\begin{array}{l}\text { Ranking/Impact } \\
\text { SCOPUS } 2018\end{array}$ & Category \\
\hline $\begin{array}{l}\text { Journal of Cleaner } \\
\text { Production }\end{array}$ & 19 & Q1/1,62 (SJR) & $\begin{array}{l}\text { Engineering industrial and manufacturing } \\
\text { engineering; environmental science; industrial } \\
\text { and manufacturing engineering; renewable } \\
\text { energy, sustainability and the environment }\end{array}$ \\
\hline $\begin{array}{l}\text { Sustainability } \\
\text { (Switzerland) }\end{array}$ & 19 & $\mathrm{Q} 2 / 0,55$ (SJR) & $\begin{array}{l}\text { Geography, planning and development; } \\
\text { management, monitoring, policy and law }\end{array}$ \\
\hline $\begin{array}{l}\text { Production Planning and } \\
\text { Control }\end{array}$ & 7 & Q1/1,43 (SJR) & $\begin{array}{l}\text { Business, management and accounting strategy } \\
\text { and management; computer science; computer } \\
\text { science applications; } \\
\text { decision sciences management science and } \\
\text { operations research; } \\
\text { engineering industrial and } \\
\text { manufacturing engineering }\end{array}$ \\
\hline $\begin{array}{l}\text { Resources, Conservation } \\
\text { and Recycling }\end{array}$ & 3 & Q1/1,54 (SJR) & Waste management and disposal \\
\hline $\begin{array}{l}\text { Journal of Industrial } \\
\text { Ecology }\end{array}$ & 1 & Q1/1,49 (SJR) & Environmental science; social sciences \\
\hline Resources & 1 & Q2/0,65 (SJR) & $\begin{array}{l}\text { Environmental science; management, } \\
\text { monitoring, policy and law nature and } \\
\text { landscape conservation }\end{array}$ \\
\hline
\end{tabular}

The first six journals in order of the number of publications are Journal of Cleaner Production; Sustainability; Production Planning and Control; Resources, Conservation and Recycling; Journal of Industrial Ecology; and Resources. The most relevant papers linking supply chain and circular economy were selected gathering a core sample of 50 papers taken into account for the purpose of content analysis. Figure 1 shows the distribution of articles in the various journal. 
ANALYSIS OF EVOLUTION OF THE PUBLICATIONS OF THE CSC CONCEPT IN THE 6 JOURNALS

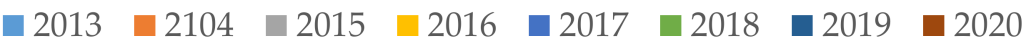

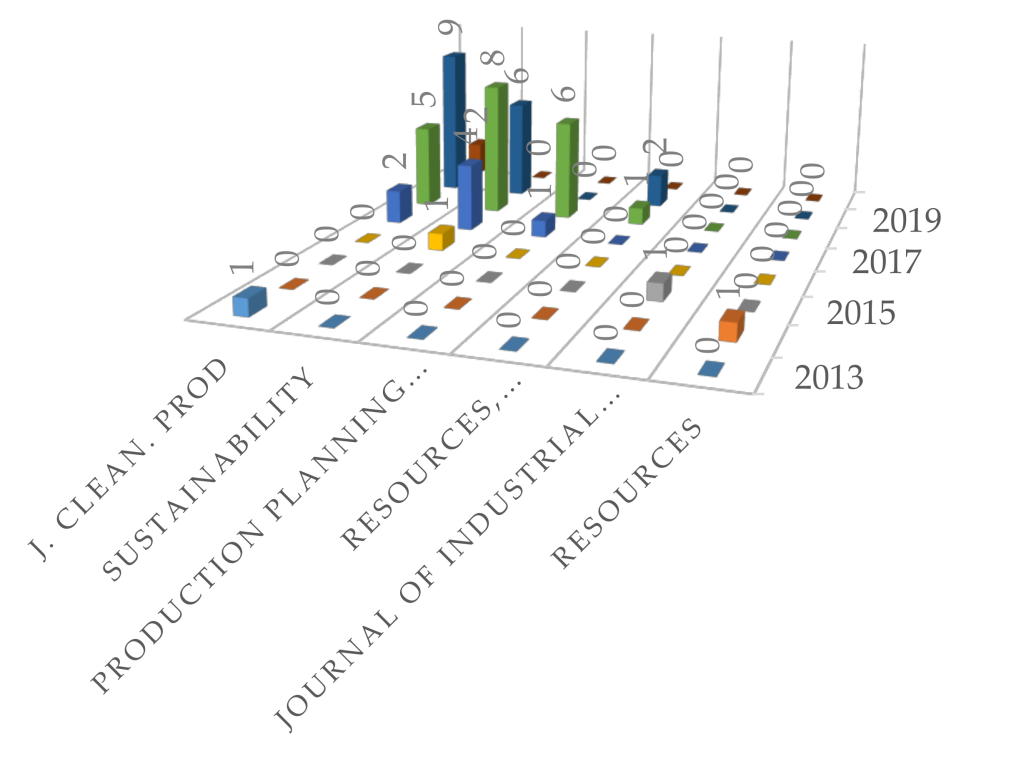

Figure 1. Analysis of the evolution of the publication of the 'circular supply chain' concept in the journals under study.

The journals with the majority of publications related to circular supply chain are Journal of Cleaner Production and Sustainability, each with 19 articles. The year 2018 is the one with the highest number of articles, followed very closely by 2019 . The temporal evolution of the 50 scientific texts analyzed in the years between 2013 and 2020 offers an ascending evolution. It is remarkable the exponential growth of the publication of articles related to circular supply chain since 2017.

\section{The Conceptualization of Circular Supply Chain}

Many papers consider Pearce and Turner as the authors who first coined the term CE in the early 1990s [16,24,30,36]. Pearce and Turner in their seminal work [37] (p. 67) considered that "scientists tend to define pollution differently from economists." In this assertion it can be established one of the main reasons that leads these authors to expose in the 90s the need to reconcile economy and environment, expanding the horizons of the economy. It implies, therefore, the passage from a linear and open economy to a circular and closed model. An industrial system that is restorative or regenerative by intention and design.

The starting point is that economic growth is directly related to flows of materials and energy [38]. The classical linear economy is based on the manufacture of short-lived products, planned obsolescence, economies of scale, and the consequent growing consumer demand for new products. While the CE is based on the consideration of the negative externalities that the consumption of resources originates [9]. Therefore, CE is focused on how to avoid, minimize, restore, and/or compensate stakeholders $[39,40]$. The application of circularity in the supply chain has two main pillars. One is based on extending the durability of products or increasing the amount of remanufacturing, repair, renovation, and recycling cycles. The second would be the extension of the period of time during which the materials are kept in use [41].

It is necessary to rethink the productive system, in such a way that CE can focus on the three Rs (reduction, reuse, and recycling), the 6Rs (reuse, recycle, redesign, remanufacture, reduce, 
recover), or the 9Rs (refuse, reduce, reuse, repair, refurbish, remanufacture, repurpose, recycle, recover) to achieve greener but also more efficient production processes, which would make them more profitable for organizations [39,42-45]. Accordingly, CE has traditionally been associated with "sustainability" [30,46-49]. It understands industry from a restorative and regenerative perspective by intention and design [3]. In this sense, it would mean the attempt to dissociate economic growth from the indiscriminate consumption of resources and goods [37], through practices that allow for optimizing the industrial system. The circular economy considers the supply chain as a critical element for its implementation, which requires the acceptance of all actors involved [50]. However, the application of practices related to other organizations is much more complex than when applied simply at the organizational level [51].

Through circular supply chains it is possible not only to reduce the production of waste, but also to achieve self-sustaining production systems in which materials are returned to the production cycle [52]. Circular supply chains apply to both the manufacturing and service sectors [53]. Various terms have been wrongly used in the literature to talk about the application of the paradigms of the circular economy-reverse supply chain, close-loop chain or open-loop chain, and green supply chain. However, it is essential to consider the main characteristics of these different types of supply chains, since although they cannot be considered as circular supply chains, they have contributed to their constitution.

\subsection{Reverse Supply Chain}

Reverse supply chain management has been developed as an adaptation of circular economy principles to supply chain management. Indeed, a reverse supply chain includes activities dealing with product design, operations, and end-of-life management in order to maximize value creation over the entire lifecycle through value recovery of after-use products either by the original product manufacturer or by a third party. Reverse supply chains are either open-loop or closed-loop [52,54]. Although the recovery of products at the end of their useful life is considered to be an environmentally friendly activity, such recovery requires an energy cost and generates pollution from the transport and subsequent treatment of the products that must be considered [55].

\subsection{Closed-loop Chain vs. Open-loop Chain}

Open-loop supply chains involve materials recovered by parties other than the original producers who are capable of reusing these materials or products. On the other hand, closed-loop supply chains deal with the practice of taking back products from customers and returning them to the original manufacturer for the recovery of added value by reusing the whole product or part of it [54]. Closed-loop supply chains expanding on reverse logistics, include remanufacturing, reuse, repair, refurbishment, and recycling [56]. They require considerable investment in resources, and then development of a collection system which takes back the product at its end-of-life [41]. Open-loop chains involve materials from several producers and closed-loop chains focus on one particular manufacturer [52].

\subsection{Green Supply Chain:}

Green supply chains engage suppliers and customers to foster environmental cooperation that will result in gains associated with both environmental and economic performance [26]. As opposed to traditional supply chain, "green supply chain management is characterized by greenness in product design, selection and purchase of raw materials, production, distribution of final products, and after sale services" [8] (p. 1284).

Two approaches can be considered when developing practices in green supply chains, based on monitoring and collaboration. In the monitoring approach, the purchasing company sets the standard for evaluating suppliers and their products. When based on the collaborative approach, buyers are required to be directly involved in improving the environmental performance of suppliers, focusing on long-term objectives [23]. 
These terms appear in literature and are used interchangeably in several papers. However, as demonstrated, there are important differences to consider between these concepts (Figure 2). Circular supply chain is a step beyond closed supply chains and green supply chains. Firstly, it expands the number of actors in the chain by also considering sectors other than that of origin. Secondly, the relationships between actors also change. Customers can return the product or its waste to any actor in the value chain of the production system within the industry sector, or with different industrial sectors [27].

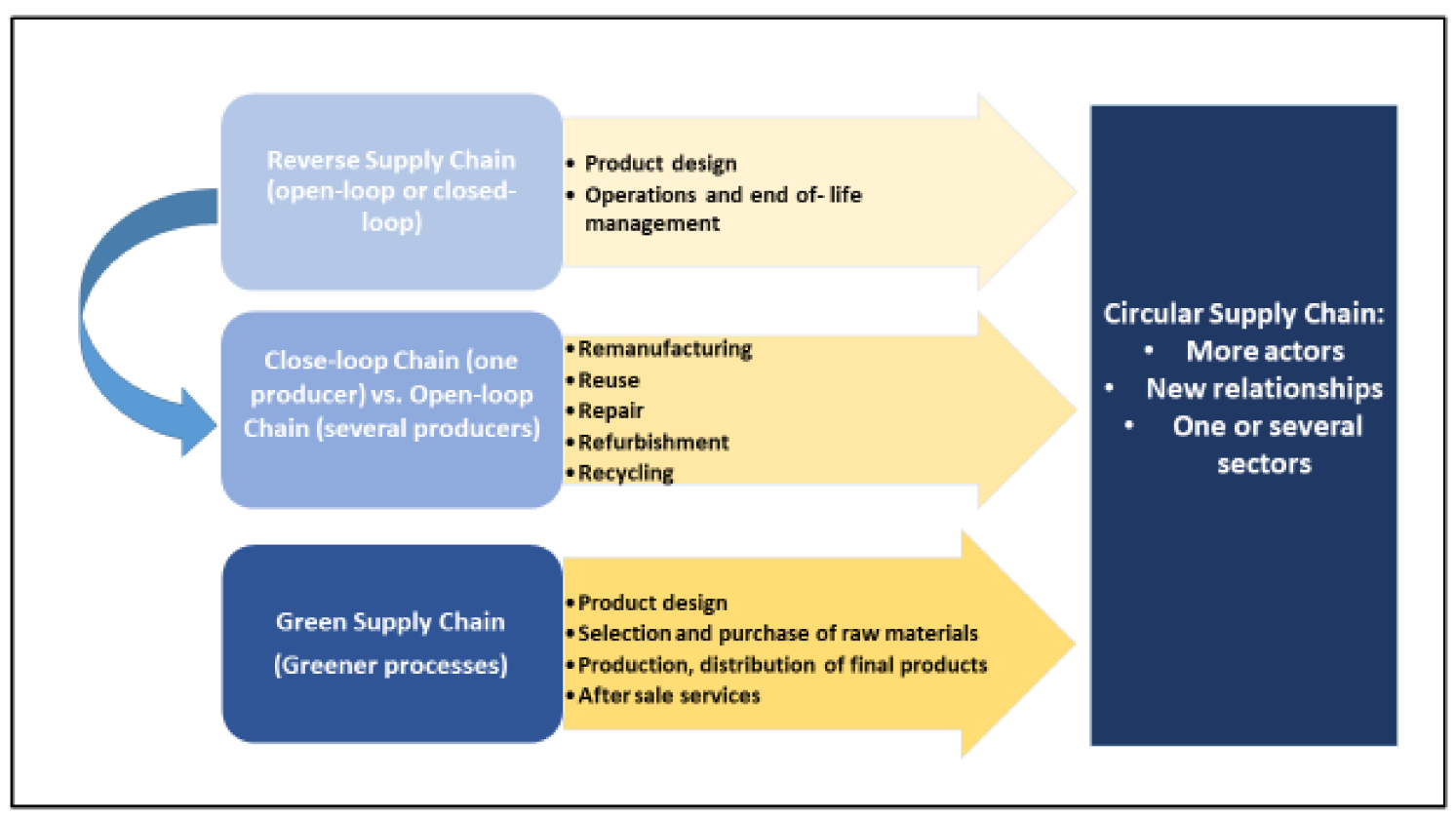

Figure 2. Contribution of the main terms related to the circular supply chain.

However, the theoretical concept needs to be translated into reality through strategies and guidelines that allow a more rational productive system to be achieved [44,57]. Six stages of maturity have been established based on a logic sequence of general management activities-problem identification, objective and intervention activities development activities, implementation and operation activities, and monitoring activities [58] (p. 23). Therefore, circular supply chain would be a guide for mapping the necessary key activities, potential challenges, and available resources so that the company can proactively develop individual and organizational tools to achieve its economic, social, and environmental objectives [30]. In such a situation, the company must rethink both the strategic activities of the company and the relationships established with external partners [59]. Therefore, we find a transformation of the value chain of the companies that wish to adopt the circular approach [44].

\section{Building the Circular Supply Chain: Dimensional Design}

\subsection{Circular Supply Chain Management (CSCM)}

Geissdoerfer et al. [60] (p. 714) define "the configuration and coordination of the organizational functions marketing, sales, R\&D, production, logistics, IT, finance, and customer service within and across business units and organizations to improve operative effectiveness and efficiency of the system and generate competitive advantages." Circular supply chain management (CSCM) offers a compelling perspective that includes the vision of a zero-waste economy and the restorative and regenerative cycles designed based on circular thinking.

For this restoration and regeneration of materials to achieve the vision of zero waste, business model and supply chain designs must be adapted with the participation of a wide range of 
stakeholders [27]. For them, distributors must be considered from a broader perspective, since they are no longer considered only as the company's suppliers-closed-loop-but also as others in the same sector-open-loop, same sector-and even in other sectors-open-loop, cross sector [61]. Decision making in supply chain management should be done with the estimation of different types of costs. This estimation generally depends on several factors that make up the supply chain [62], which will be analyzed from the main theoretical perspectives in strategic management literatures.

\subsection{Theoretical Perspectives in Strategic Management Literature}

The resource-based view (RBV) [63-65] contributes to a better understanding of how the company as a whole works, as well as the resources and competencies fundamental for the company to redesign its operations in response to a change in competitive conditions. "Companies need certain dynamic capabilities and organizational routines to deal with the increased complexity of managing innovation from a sustainable perspective" [66] (p. 225). The capacities, routines, and resources included in the business model must allow, on the one hand, the detection of opportunities with the objective of obtaining valuable knowledge about the business habitat [67], and on the other hand, seizure through organizational capacities to take advantage of recognized opportunities and create value from them [68]. Both must achieve the implementation of new products, services, or processes [66]. Therefore, "RBV is considered as an adequate theoretical framework to understand whether specific resources applied to the $\mathrm{CE}$ by businesses are relevant for closing production loops without affecting the level of competitiveness" [69] (p. 3).

Industrial ecology (IE) can be defined as a policy with the aim of reducing the amount of waste creation by examining the flows of materials and energy in industrial systems as closing the material flow loop efficiently $[70,71]$. "The IE enables understanding how the industrial system works, how it is regulated, and what interactions it presents, to restructure it in order to make it similar to natural systems" [72] (p. 2). For all that, circular supply chain incorporates concepts and ideas from IE.

The agency theory will also condition how it operates, since the company (who act as principal) must ensure that the different primary stakeholders (customers or suppliers) will behave in accordance with the contractual terms established. These terms should enable the achievement of business objectives related both to the provision of sustainable services and to the sale and recovery of products at the end of their useful life [31,73]. It must therefore consider temporal aspects that would be related to the technical life of the product and the duration of the cycle of use of the same one [72]. The value chains can be mapped to visualize the linkages and interactions between the different stages and chain actors to understand the complexities of such multi-actor systems and make informed decisions regarding the coordination and balance among stakeholders of a supply chain [74,75]. For this reason, [45] consider that greater intensity is required in the relationships established in the supply chain and with customers. It implies a change of focus, focusing on the life cycle of the product and not on the quantity of the product produced.

Strategic networks are stable inter-organizational links which are of importance to the company and which express these links through various forms, such as strategic alliances or long-term buyer-supplier partnerships [76]. The network perspective is of great relevance for understanding value creation in the circular economy due to the importance of the networks that are formed between companies, their suppliers, their customers, and other relevant partners [60].

The configuration of the network in terms of density and centrality [77] and the importance of governance mechanisms such as trust. Other sources of value in strategic networks include shortened time to market [78], enhanced transaction efficiency, reduced asymmetries of information, and improved coordination between the firms involved in an alliance [76]. It seeks "to change organizational mindsets to facilitate collaborative knowledge development and sharing, the creation of shared visions, and collaborative value propositions" [79] (p. 23).

In the context of institutional theory, companies incorporate social legitimacy through adopting the norms and social traditions predominant in their environment [23]. Powerful institutions have an 
option of implementing policies which boost organizations and the population to adopt a practice [80]. The environment of the circular economy is governed by new rules and customs that revolutionize social, cultural, and political models.

From the main theoretical perspectives of strategic management literature, we propose four main dimensions that would allow us to classify the main factors found in the literature review (Figure 3). In the following sections we will carry out a detailed analysis of these dimensions and their variables, to finally propose a conceptual model to support the design and implementation of circular supply chains.

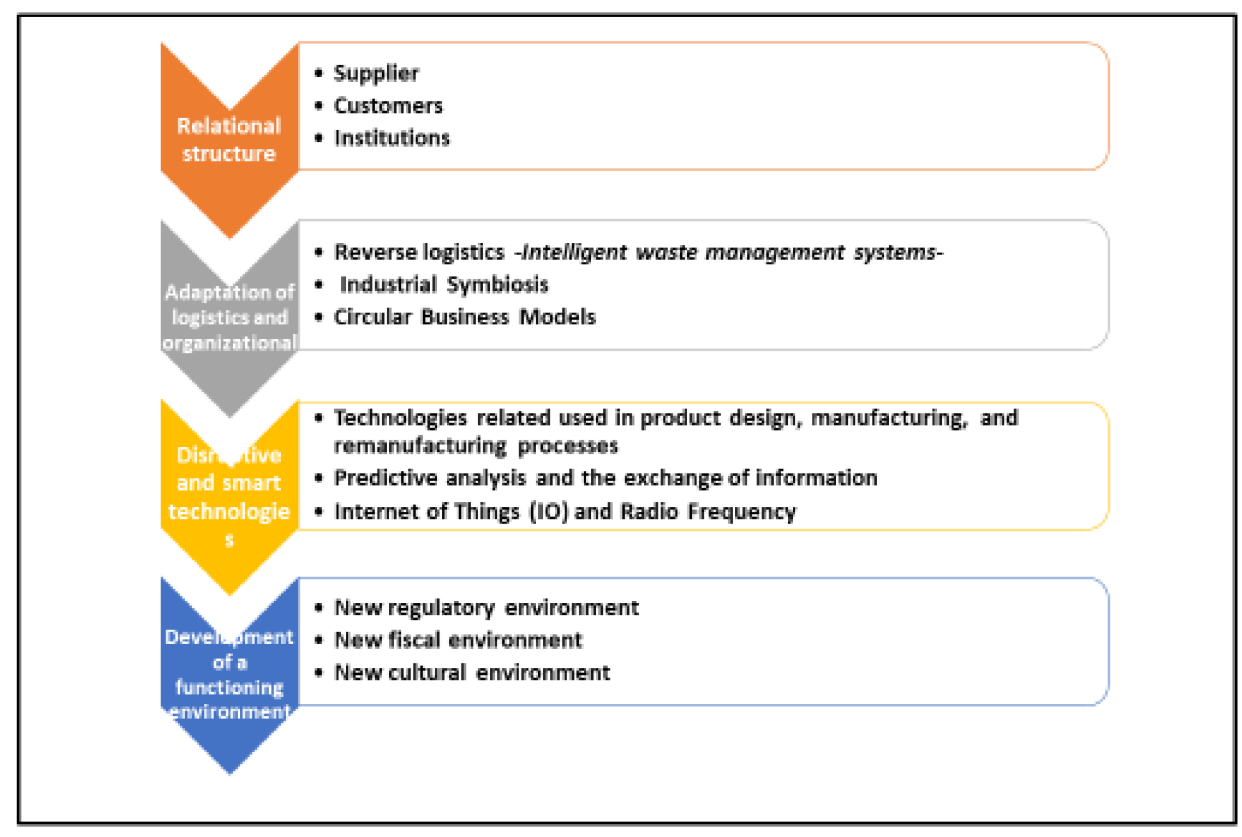

Figure 3. Main dimensions in the design of circular supply chains.

\subsection{Relational Structure}

There are different actors involved in the supply chain with different organizational management structures [81]. Current configurations of the supply chain must be redesigned to implement the exchange of waste and industrial by-products considering the principles of the circular economy [56]. This problem involves "a variety of stakeholders, demands behavioral changes, and requires a complete rethinking of the current waste management systems and the dominant linear economic model" [82] (p. 1). Circular thinking must be applied at all stages of the supply chain and go beyond the boundaries of the sector [27]. This involves different stakeholders from a broader perspective than has been done in the traditional supply chain. It is not only a question of change in the productive system, but also of incorporating relations between the agents involved. Collaboration in the supply chain enables a network of actors to be connected in their supply chain by managing the transparency of data, flows and exchanges of material, responsibilities, predictability, and benefit sharing $[4,83]$.

"Supply chain management involves different actors and a socio-ecological system which explains tensions and driving forces in the management of the supply chain" [50] (p. 4). Sharing a vision of the future in $\mathrm{CE}$, in particular in an early stage, makes it possible to achieve clear collective goals and serves as inspiration, motivation, and direction [83]. Cooperation between internal or external stakeholders in the supply chain will also facilitate the exchange of information, whereas industrial symbiosis networks facilitate the need for exchange of by-products, materials and energy between producers [41,84]. There are environmental considerations for circular supply chain design that consider the flow of materials and energy between different companies, allowing the formation of an industrial system of symbiotic exchange of resources and waste products [85]. The company leading the process will be a crucial actor in the supply chain, as its decisions will have a cascading effect on the other actors. 
Furthermore, it can serve as a reference when it comes to transferring sustainable practices into the productive process [50]. For all these reasons, it is necessary to study the new relationships that are established with all the players involved in the circular supply chain.

\subsubsection{Suppliers}

"Suppliers, as the first layer of the supply chain network, pose a great impact on environmental pollution" [62] (p. 1). In addition, the relationship with suppliers becomes closer, in such a way that efficient management of resources is shared. It is essential to make a correct selection of the suppliers to guarantee lower costs of treatment of the materials and a lower environmental impact, reducing the distribution centers and the vehicles used. Therefore, it is necessary to create a framework to structure the decision-making problems and use the methods to decide between multiple alternatives [62]. The selection process can be completed with further development of suppliers to improve the performance of the existing supplier [2].

One problem to consider is the inventory-location and routes $[62,86]$, so it would be convenient to consider a smaller number of trips and with shorter routes. The routes for a fleet of vehicles could be optimized with regard to costs and emissions [55]. New tools can be used for this purpose, such as novel diploid evolutionary algorithm for the truck scheduling problem [3]. The direct impact of both direct transport-transport between the buyer and the first-tier supplier-and indirect transport-transport following the trade operations between different geographical markets-by suppliers in the circular supply chain should be considered in the environmental impact [86]. So, it is recommended to favor local suppliers located in the final markets in order to reduce the costs of indirect transport in the circular supply system $[62,86]$.

There are additional criteria in the selection of suppliers' waste handling activity they affect to estimate the net environmental impact. Reducing the pre-deposition of waste in landfills, avoids producing additional emissions. In addition, it is important to consider the level of usability of the waste with respect to the virgin raw material. Poor usability would lead to additional emissions and changes in productivity [86].

\subsubsection{Customers}

In the linear economy, customers are the final link in the supply chains, playing a passive role. In the circular economy, among other actors in the supply chain, customers are required to take an active part in the recovery of products and the recycling of waste materials [87]. The customer becomes a key participant in the strategic network that is developed in the circular economy, so it is essential to promote loyalty and satisfaction to establish a longer-term relationship. "Firms have been increasingly influenced by customers' ethical values and ecological thinking, pushing them to address environmental management practices" [2] (p. 4). Companies applying the principles of the circular economy in their supply chain should share common objectives and cooperate with customers to encourage green purchasing behavior [8].

However, within the framework of the circular economy, it is necessary to further evolve customer behavior and values to reduce the environmental impact of products in the usage stage [2]. The transition to $\mathrm{CE}$ requires changes in the behavior of customers both in their consumption and in the treatment of the waste they produce. These changes can be brought about through the implementation of awareness campaigns and education for sustainability [27].

In this context, the ownership of the product that the company has manufactured does not end with the sale of it. In fact, the productive system must contemplate the reincorporation of the product to the productive process. In this sense, the useful life of the products acquires a new dimension. For this reason, we can consider a change of model in which the sale is associated to the utility of the product, and not to the naked property of the same one. A collaborative consumption model needs to be developed for improved interaction among customers, suppliers, and retailers to access to products rather than ownership of products [19]. For that reason, it is necessary to consider, in diverse industries, 
other commercial relations with clients beyond sales [1]. Thus, customers could participate actively by sharing their solutions and by providing feedback [50]. "Supply chains can become sustainable and improve their economic and socio-environmental performance by motivating customer behavior toward green consumption patterns, which, in turn, motivate producers and suppliers to change their operations" [55] (p. 652). Customers' behavior directly affects the capacity of the market. In the supply chain, in order to influence such behavior, it should consider the difference between the cost of the warranty for new products and remanufactured products and extend the customers' utility function from the consumer's perspective, optimizing warranty period decisions [88].

Another tool when it comes to influencing customer behavior is the design of proper reward programs. In contrast to the prevailing assumption of customer preference for monetary compensation as driver to participate, current papers have shown that customers may prefer rewards associated with facilitating the collection process of waste or products [87]. Integrating the customer behavior approach into the supply chain would lead to a more evolved model that they have called the extended sustainable supply chain, which considers both environmental factors and strategies for change [55].

\subsubsection{Institutions}

Institutional pressure is considered to be the influence exerted by the institutional environment through social norms, rules, and/or culture. This pressure has a significant positive impact on supply chain relationship management and sustainable supply chain design [85]. Governments could promote public demand of sustainable products and a greater involvement to support the implementation of circular economy practices [50]. They can develop appropriate policies, guidelines, plans, measures, and targets for the long-term promotion of the CE and sustainable society $[89,90]$.

Government intervention with respect to the application of dynamic intervention mechanisms or subsidies should be conditioned by the preferences of clients or consumers [91]. "Many governments around the world have also introduced a series of remanufacturing policies and regulations to encourage and guide enterprises to focus on the source of sustainable development" [92] (p. 16).

In view of the above, we propose the following proposals related to external relations.

Proposition $1\left(\mathbf{P}_{1}\right)$. Collaboration within the supply chain network positively affects environmental and economic performance of circular supply chains.

$\mathbf{P}_{1.1}$. Correct selection of the suppliers positively affects environmental and economic performance of circular supply chains.

$\mathbf{P}_{1.2}$. Designing tools to influence customer behavior positively affects environmental and economic performance of circular supply chains.

$\mathbf{P}_{1.3 .}$ Institutional pressure through social norms, rules, and/or culture positively affects environmental and economic performance of circular supply chains.

\subsection{Adaptation of Logistics and Organizational Management}

The change implied by the application of the principles of circular economy in the supply chain requires the adaptation of the organization, in general, and of production, in particular. For this purpose, three fundamental related concepts are analyzed-reverse logistic, industrial symbiosis, and circular business models.

Reverse logistics are fundamental to the application of CE principles in supply chain logistics, both in achieving greater extraction of product value and in the reuse of materials or products [27]. All members in the supply chain must be involved for the true operationalization of reverse logistics [93]. The literature review also relates that reverse logistics is a key component of remanufacturing [94]. "Remanufacturing is emerging as one of the closed-loop supply chain approaches for the circular economy but it is beneficial and successful only if the products are designed for remanufacturing. 
Remanufacturing is the only circular business model which provides the latest feature and warranty to the products" [90] (p. 2). The technique allows commodities to be moved from where they have been consumed to the place where they will be processed to capture value or appropriate disposal; aspects such as packaging or the geographical dispersion of points of consumption are essential $[80,89]$. The focus would be on efficient packaging design strategies abiding regulations and utilizing end-of-life of packaging material [34].There is a need for a systemic approach in understanding the relationship between packaging and supply due to the significant global footprint of multiple product physical supply chains [80].

Associated with reverse logistics, the adaptation of waste management systems must also be developed. Intelligent waste management systems involve both infrastructure and management aspects, but also aspects related to the behavior of citizens, product designers, producers, and policy makers. The functions in this system consider from the design of the products or services to the end-of-life management [82,95]. The involvement of the main actors is essential to control or to decrease waste generation $[36,82]$. So, the capacities analyzed must be completed with the relational capacity that considers a wide range of interests of the different stakeholders, both internal and external. As for suppliers and customers, the relational capacity must turn them into strategic factors, managing to develop "supply loops" in such a way that the company can choose suppliers offering better-performing materials, or recover products, components, and materials used and incorporate them back into the productive system in a systematic way $[46,66,73,96]$.

Within this relational capacity we find the industrial symbiosis that favors the transformation of waste from a process into input or raw material between companies that work together, whether or not they belong to the same industry [44]. This could mean that linking value chains would require new governance structures-incentive intensity, administrative control, autonomous adaptation, and coordinated adaptation-with hybrid and hierarchical characteristics to better face with the interdependencies resulting from current transactions [97].

Finally, a new business model is required to develop more integrated systems that enable moving from products toward associated services and reuse practices. The circular business model implementation encourages the design of circular or reverse supply chains, allowing products at the end of their life cycles to reenter the supply chain as production [81]. So, a circular business model could provide managerial practices for design and implementation of supply chain [29]. There are a wide number of business model archetypes that can be used as a starting point $[29,98]$. Some studies propose some business models that favor the implementation of circular supply chains. For example, $[29,95,99,100]$ confirm that product service systems (PSS) business models have the potential to trigger and enhance the circularity features of supply chains, which can be complemented by other tools, such as the sustainable value analysis tool, to assist practitioners.

It should be considered that reuse needs to be developed in a profound way, both considering the characteristics of the material itself, as well as its quality or usefulness, and analyzing aspects of the market. There are differences between sustainable business models and circular business models, since the latter not only create sustainable value, but also involve dynamic and continuous management, allowing the loops of resources to be modified [20,30]. To reach this, structural, cultural, and social change must be achieved. "Shifting toward a circular model may offer enormous opportunities, including cost savings through waste reduction, better supply chain management, lower sensitivity to resource price volatility, and longer, better relationships with customers" [31] (p. 4). In relation to the work to be done on relationships, [72] state that promoting collaboration between external and internal stakeholders is part of the model.

Then, our proposals are defined as follows:

Proposition $2\left(\mathbf{P}_{2}\right)$. The adaptation of organizational and productive structures positively affects environmental and economic performance of circular supply chains. 
$\mathbf{P}_{2.1}$. Reverse logistic positively affects environmental and economic performance of circular supply chains.

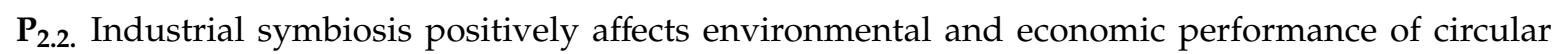
supply chains.

$\mathbf{P}_{\text {2.3. }}$ Circular business models positively affect environmental and economic performance of circular supply chains.

\subsection{The Use of Disruptive and Smart Technologies}

Considering the complexity of applying the circular economy approach to the supply chain, the sector requires a deliberate and detailed monitoring system which should be adaptive to technological changes $[5,34,101]$. The new smart technologies allow the development of new functionalities necessary for productive and management change [58].

Industry 4.0 term is used for the fourth industrial revolution incorporating factors such as the Internet of Things (IoT), augmented reality, additive manufacturing (AM), big data, cloud computing, simulation, industrial automation, and cybersecurity [102]. As far as technology is concerned, there is still a long way to go. Smart enabling technologies in a circular framework can help both to facilitate efficient monitoring, collection, separation and transport of waste for value recovery and proper disposal, as in recent years, to data acquisition and communication technologies [82]. Current material recovery technologies are opportune to control phases by penalizing incorrect behaviors [5],

We can consider different typologies according to the objective sought in the supply chain. Firstly, those technologies related used in product design, manufacturing, and remanufacturing processes to a reduction of production costs and to achieve more sustainable operations-such as augmented reality technology, intelligent robots, or 3D printing for CSCM [92]. For example, those related to extending the life cycle of products, eliminating programmed obsolescence. Similarly, the rapid development of network technology has also allowed the development of the electronic channel, with the advantages of fewer intermediaries and greater efficiency in control and lower inventory risk [91].

Secondly, new technological tools now allow predictive analysis and the exchange of information with stakeholders. Developing computer tools based on collaborative platforms building waste analytics to report in the supply chains is important to ensure that the value of materials is sustained within the economic circle [24]. So, it is necessary to go deeper into the functions of big data in circular supply chain management, as they allow for predictive analysis of supply chain sustainability performance $[27,103]$.

Thirdly, the Internet of Things (IO) and radio frequency; through the Internet of Things (IO) and the Internet of services, information is monitored, controlled, and transferred, orienting the actions to be developed. Industry 4.0 has enabled the design, planning, and operation of sustainable supply chains that ensure the incorporation of environmental protection into supply management [53]. Identification technologies (Radio Frequency Identification (RFID), Near Field Communication (NFC) sensors, Global Positioning System (GPS), etc.) can be used to improve traceability and to improve product life cycle information management [20]. These technologies facilitate real-time data collection and inform effective decision-making in restoration activities [82].

Achieving more economical and targeted technologies can facilitate processes in circular supply chains, since the exchange of technologies and the innovation that makes it possible to improve the operation of the whole chain [89]. Supported by this technological revolution, are new theoretical concepts of relevance. The integration of Industry 4.0 in the circular economy allows the optimization of the use of resources and energy by implementing disruptive technologies, although it is in its early stages $[27,53]$.

All these arguments encourage us to propose that: 
Proposition $3\left(\mathbf{P}_{3}\right)$. Smart technologies implemented with sustainable practices positively affect environmental and economic performance of circular supply chains.

\subsection{Development of a Functioning Environment: New Regulatory, Fiscal, and Cultural Environment}

Circular supply chains take on a global character, however, economic viability will depend on government support in their implementation [52], which implies having to manage legislation from different regions and their corresponding regulations [50]. It would be necessary to reach a systematic regulation and policy system, with better interactions among policy makers, governments, industry, and society [28]. An absence of firm legislative mechanism affects the manufacturing firm's decisions to incorporate eco-friendly solutions to their operations [19]. "Due to the lack of regulatory pressures, organizations tend to continue the status quo of waste management, which is often a neglected part of supply chain operations management" [82] (p. 5).

Stricter government regulations around the world will place responsibility on all actors in the supply chain for implementing the necessary measures, for example, facilitating the adoption of reverse logistics initiatives. Establishing shared responsibility laws for waste management would involve manufacturers, retailers, government, waste pickers, and customers, which would facilitate both collaboration between actors and the attribution of responsibilities [93]. Government regulations need to prescribe clear guidelines for operating within each step of the supply chain and enforce penalties for non-compliance [84]. In summary, it would be desirable, in order to encourage the implementation of circular supply chains, that regulatory intervention at government and European Commission level brings clarity to the law so that it does not prevent CE collaboration [41].

Sectoral agreements are critical instruments as formalization is expected to encourage companies in the supply chain to implement, for example, logistics systems for waste [93]. This fact is important if we consider that sectors can act as important transmission centers between suppliers and consumers in the global network, providing additional information [104]. Whereas in circular supply chains there is a need for greater collaboration at a horizontal level between supply chains and between different industry sectors, therefore cross-sectoral standards are required through legislation, beyond the voluntary cooperation that arises at company level [41]. However, in order to properly design policy interventions in specific sectors through supply chains, affected communities must first be identified [104].

A lack of economic benefits in the short run can be understood as the increasing short-term cost [19]. In addition, many organizations find it difficult to obtain financial resources to improve their waste management, especially if they deal with it on an individual basis, as this prevents them from achieving scale economies [82]. In this sense, it is key to carry out correct fiscal management by the corresponding institutions, so that, for example, recycling can be encouraged by exempting recycled products and even post-consumer waste from taxes [89]. In this line, it would also play a role to consider subsidies that encourage the use of renewable energy, penalizing those that are more polluting [5].

Finally, the cultural environment that frames the application of the principles of the circular economy must be considered. Cultural changes in both society and business must be considered. The lack of environmental education and the protection in the adult generation is reflected in mentalities, habits, and behaviors that often do not take into account protection of the environment, and behavior that is difficult to change [82].The development of a new organizational culture is essential for the implementation of greener supply chains [19]. Developing an organizational culture can overcome the lack of human resource capabilities that can be a crucial obstacle to achieving implementation of the circular supply chain.

Based on all the above arguments, we formulate the following proposals:

Proposition $4\left(\mathbf{P}_{4}\right)$. The design of a new legislative, fiscal, and cultural framework positively affects environmental and economic performance of circular supply chains. 
$\mathbf{P}_{\text {4.1. }}$ Legal requirements to include the CE principles positively affects environmental and economic performance of circular supply chains.

$\mathbf{P}_{\text {4.2. }}$ The design of fiscal tools positively affects environmental and economic performance of circular supply chains.

$\mathbf{P}_{4.3}$. The development of a new cultural framework that facilitates the flow of knowledge in social and business environments, positively affects environmental and economic performance of circular supply chains.

As a conclusion of the literature analysis, a theoretical model has been drawn. Figure 4 provides a graphic depiction of the proposed analysis model. The different blocks of the model are correlated with each other by the propositions enunciated in the theoretical framework and built on the basis of the analysis of the literature. The strategic objective of the model takes up the challenge arising from the research question: What are the dimensions that allow the design of circular supply chains? What kind of challenges do they pose?

Four fundamental dimensions have been identified when developing and implementing circular supply chains-greater intensity in the relationships established in the supply chain, adaptation of logistics and organizational, disruptive and smart technologies, and a functioning environment. These dimensions apply both within the organization and in its environment. For this reason, the total commitment of the different actors involved-organizations, clients, institutions, etc.-is necessary.

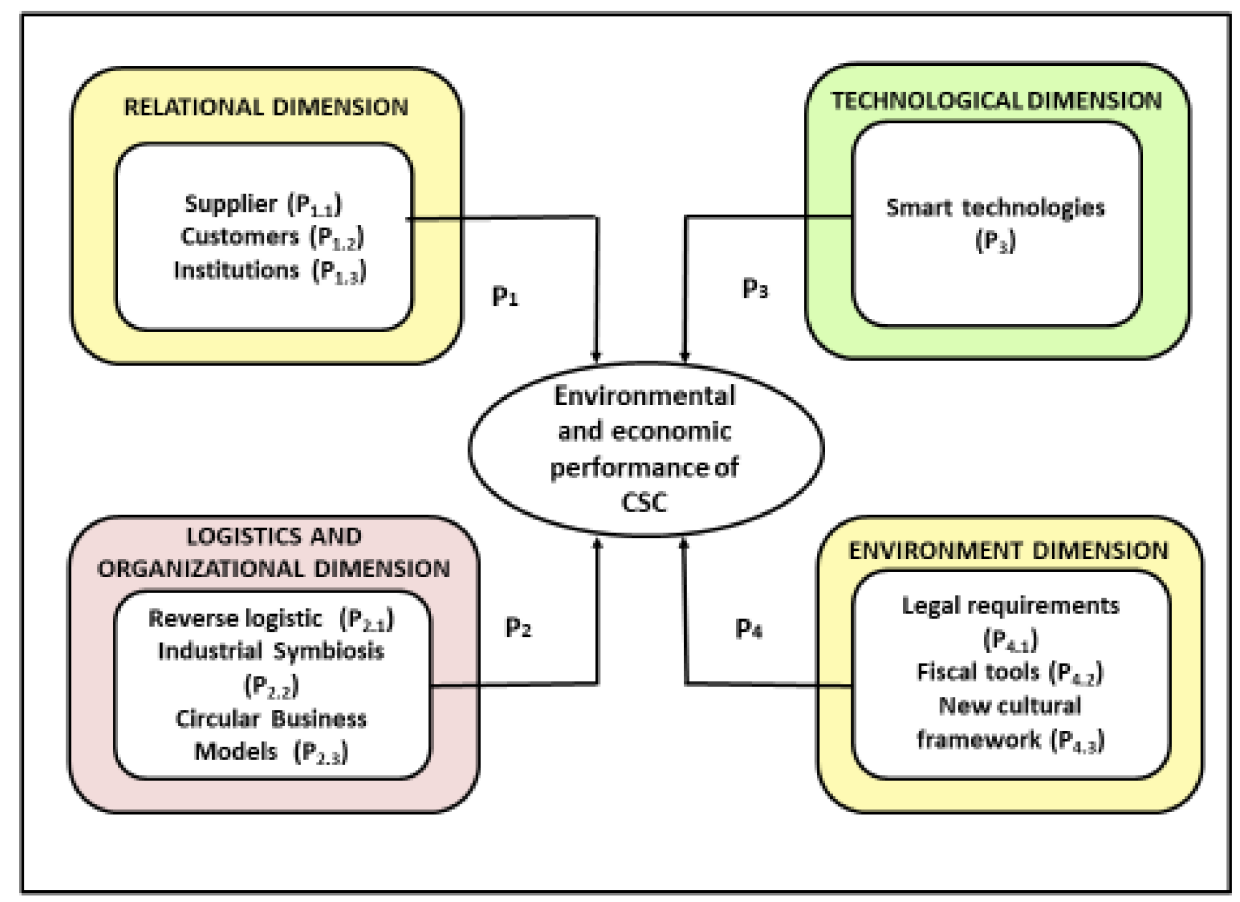

Figure 4. Conceptual model for the integration of circular economy into supply chains.

To summarize, Table 2 shows the definitions, configurations and enablers of the supply chains associated with the circular economy by the main papers analyzed. 
Table 2. Summary of the concept 'circular supply chain' in the main articles analyzed.

\begin{tabular}{|c|c|c|c|c|}
\hline Authors & Denomination & Definition & Configurations (C) or indicators (I) tools & Enablers (E) or Inhibitors (I) \\
\hline Chu et al. (2017) [23] & Green supply chain & $\begin{array}{c}\text { A set of practices that combines environmental issues with } \\
\text { supply chain (SC) management in order to guarantee } \\
\text { environmental compliance and promote the } \\
\text { environmental capability. }\end{array}$ & $\begin{array}{c}\text { Environmental performance, environmental } \\
\text { management systems, environmental audits, } \\
\text { demand for greener products, useful information, } \\
\text { technical assistance, and joint development of } \\
\text { products (I). }\end{array}$ & $\begin{array}{l}\text { Institutional } \\
\text { pressures-government, } \\
\text { customer, and competitor } \\
\text { pressures (I). }\end{array}$ \\
\hline $\begin{array}{l}\text { De Angelis et al. } \\
\text { (2017) [41] }\end{array}$ & Circular supply chain & $\begin{array}{c}\text { The embodiment of circular economy (CE) principles within } \\
\text { supply chain management. }\end{array}$ & $\begin{array}{l}\text { Shift from product ownership; structural flexibility } \\
\text { and start-ups in regional/local } \\
\text { loops; open and closed material loops in technical } \\
\text { and biological cycles; closer collaboration; } \\
\text { and public and private procurement in the service } \\
\text { industry (C). }\end{array}$ & N.A. \\
\hline Masi et al. (2017) [26] & Circular supply chain & $\begin{array}{c}\text { A critical unit of action for the implementation of the CE } \\
\text { because of the necessity for joint effort beyond organizational } \\
\text { boundaries to involve external coordination with } \\
\text { upstream partners. }\end{array}$ & $\begin{array}{l}\text { Eco-industrial parks, environmental or green SCs, } \\
\text { and closed-loop SCs (C). }\end{array}$ & $\begin{array}{l}\text { Financial, technological, } \\
\text { societal, informational, } \\
\text { and institutional (E). }\end{array}$ \\
\hline $\begin{array}{l}\text { Geissdoerfer et al. } \\
\quad(2018)[60]\end{array}$ & Circular supply chain & $\begin{array}{l}\text { The supply chain that allows to close, narrow, slow down, } \\
\text { intensify, and dematerialize resource loops. }\end{array}$ & $\begin{array}{l}\text { Value proposition in terms of economic, } \\
\text { environmental, and social value the firm aim at } \\
\text { delivering; creation and delivery system with } \\
\text { focus on the role of the business in closing the loop } \\
\text { of the product life cycle; and value captured by the } \\
\text { various stakeholders. }\end{array}$ & $\begin{array}{l}\text { Economic, environmental, } \\
\text { and social goals; proactive } \\
\text { stakeholders management; } \\
\text { and long-term perspective (E). }\end{array}$ \\
\hline $\begin{array}{l}\text { Kazancoglu et al. } \\
\quad \text { (2018) [8] }\end{array}$ & Green supply chain & $\begin{array}{l}\text { It provides the resource optimization and it is seen as a solution } \\
\text { to solve environmental problems and consumption patterns } \\
\text { within the whole supply chain. }\end{array}$ & $\begin{array}{l}\text { Environmental performance; economic/ } \\
\quad \text { financial performance; operational } \\
\text { performance; logistics performance; organizational } \\
\text { performance; and marketing performance (I). }\end{array}$ & N.A. \\
\hline $\begin{array}{l}\text { Leising et al. (2018) } \\
\text { [83] }\end{array}$ & $\begin{array}{l}\text { Circular supply } \\
\text { chain collaboration }\end{array}$ & $\begin{array}{l}\text { It enables connecting a network of actors in their supply chain } \\
\text { by managing data transparency, material flows and exchanges, } \\
\text { responsibilities, predictability, and sharing benefits. }\end{array}$ & $\begin{array}{l}\text { Actor learning; networks dynamics; } \\
\text { business model; and visions (C). }\end{array}$ & N.A. \\
\hline $\begin{array}{l}\text { Mangla et al. (2018) } \\
{[19]}\end{array}$ & $\begin{array}{l}\text { Circular supply } \\
\text { chains }\end{array}$ & $\begin{array}{l}\text { Application of reuse, recycling, and remanufacturing to circular } \\
\text { model of flow of products, by-products, and waste. }\end{array}$ & N.A. & $\begin{array}{l}\text { Driving barriers; linkage barriers; } \\
\text { autonomous barriers; and } \\
\text { dependent barriers (I). }\end{array}$ \\
\hline $\begin{array}{c}\text { Mishra et al. (2018) } \\
\text { [98] }\end{array}$ & $\begin{array}{l}\text { Closed-loop supply } \\
\text { chain (CLSC) }\end{array}$ & $\begin{array}{l}\text { The design, control, and operation of a system to maximize } \\
\text { value creation over the entire life cycle of a product. }\end{array}$ & $\begin{array}{l}\text { Circular design; business model design; forward } \\
\text { and reverse supply chain. }\end{array}$ & $\begin{array}{l}\text { Strategic leadership for CE } \\
\text { enabled CLSC program, systems, } \\
\text { and training program; chemical } \\
\text { hazards; and legislation } \\
\text { circularity scorecard (E). }\end{array}$ \\
\hline
\end{tabular}


Table 2. Cont

\begin{tabular}{|c|c|c|c|c|}
\hline Authors & Denomination & Definition & Configurations (C) or indicators (I) tools & Enablers (E) or Inhibitors (I) \\
\hline $\begin{array}{l}\text { Prosman and Sacchi } \\
\quad \text { (2018) [86] }\end{array}$ & $\begin{array}{l}\text { Circular supply } \\
\text { chains }\end{array}$ & $\begin{array}{l}\text { A leap towards a more environmentally friendly economy that } \\
\text { includes forward supply chains and reverse activities. }\end{array}$ & $\begin{array}{l}\text { Supplier selection criteria-induced transport; } \\
\text { affected waste handling activity; and usability of } \\
\text { discarded products. }\end{array}$ & N.A. \\
\hline $\begin{array}{l}\text { Vlajic et al. (2018) } \\
\quad[105]\end{array}$ & $\begin{array}{l}\text { Circular supply } \\
\text { chains }\end{array}$ & $\begin{array}{l}\text { Concept that considers value recovery in } \\
\text { the context of circular flows, as well as those elements that } \\
\text { might affect their creation. }\end{array}$ & $\begin{array}{l}\text { Product residual value; quantities available for } \\
\text { recovery; value from recovery; and markets for } \\
\text { recovered (I) products. }\end{array}$ & N.A. \\
\hline $\begin{array}{l}\text { Yang et al. (2018) } \\
\text { [99] }\end{array}$ & $\begin{array}{l}\text { Circular supply } \\
\text { chains/closed-loop } \\
\text { supply chain }\end{array}$ & $\begin{array}{l}\text { The design, control, and operation of a system to maximize } \\
\text { value creation over the entire life cycle of a product with } \\
\text { dynamic recovery of value from different types and volumes of } \\
\text { returns over time. }\end{array}$ & $\begin{array}{l}\text { Product-service systems business models-power } \\
\text { of the inner circle; power of circling long; power of } \\
\text { cascaded; and power of pure circles (C). }\end{array}$ & N.A. \\
\hline $\begin{array}{l}\text { Coenen et al. (2019) } \\
{[58]}\end{array}$ & $\begin{array}{l}\text { Closed-loop supply } \\
\text { chain }\end{array}$ & $\begin{array}{l}\text { It serves the circular economy because developments such as } \\
\text { climate change and resource scarcity have become serious } \\
\text { issues in global politics. }\end{array}$ & $\begin{array}{l}\text { Six maturity stages-based on the well-known } \\
\text { capability maturity framework and the concept of } \\
\text { double-loop learning. }\end{array}$ & N.A. \\
\hline Daú et al. (2019) [53] & Supply chain 4.0 & $\begin{array}{l}\text { It, by bringing the disruptive technologies together in their } \\
\text { supply chains, brings together, in addition to Industry } 4.0 \\
\text { technologies, sustainable practices. }\end{array}$ & Time, infrastructure, cost, and institutional (C). & Smart technologies (E). \\
\hline $\begin{array}{l}\text { de Oliveira et al. } \\
\text { (2019) [89] }\end{array}$ & Circular supply chain & $\begin{array}{c}\text { It is based on sustainable supply chain narratives, including } \\
\text { reverse logistics, } \\
\text { sustainable supply chain management (SSCM), and closed-loop } \\
\text { supply chains (CLSC). }\end{array}$ & $\begin{array}{c}\text { Reverse logistics, sustainable supply chain } \\
\text { management (C), and closed-loop supply } \\
\text { chains (C). }\end{array}$ & $\begin{array}{l}\text { Logistics and economic } \\
\text { challenges, technology and } \\
\text { innovation, consumer } \\
\text { knowledge and legislation (E). }\end{array}$ \\
\hline $\begin{array}{l}\text { Duan et al. (2019) } \\
\text { [91] }\end{array}$ & $\begin{array}{l}\text { E-channel closed-loop } \\
\text { supply chain network } \\
\text { (E-CLSCN) }\end{array}$ & $\begin{array}{l}\text { Closed-loop process of } \\
\text { resources-production-consumption-collection-remanufacturing } \\
\text { under the e-channel to emphasize the simultaneous } \\
\text { improvement of social and environmental benefits to realize the } \\
\text { sustainable development of economy and society, while } \\
\text { achieving economic benefits. }\end{array}$ & Multi-period CLSCN (C). & $\begin{array}{l}\text { Social and government } \\
\text { participation (E), uncertain } \\
\text { factors }(\mathrm{I}) \text {, and consumers' } \\
\text { behavior }(\mathrm{E}) \text {. }\end{array}$ \\
\hline $\begin{array}{l}\text { Farooque et al. } \\
\quad(2019)[27]\end{array}$ & Circular supply chain & $\begin{array}{l}\text { The integration of circular thinking into the supply chain and } \\
\text { its surrounding industrial and natural ecosystems. }\end{array}$ & $\begin{array}{c}\text { Focused on product-level circularity or } \\
\text { focused on value-based assessment of resource } \\
\text { efficiency and CE related performance of supply } \\
\text { chain actors (I). }\end{array}$ & $\begin{array}{l}\text { Geographic and industrial } \\
\text { contexts (E). }\end{array}$ \\
\hline $\begin{array}{l}\text { Meherishi et al. } \\
\text { (2019) [80] }\end{array}$ & $\begin{array}{l}\text { Sustainable } \\
\text { packaging in supply } \\
\text { chain management } \\
\text { (SPSCM). }\end{array}$ & $\begin{array}{c}\text { Use of packaging layers and associated waste along the supply } \\
\text { chain. }\end{array}$ & $\begin{array}{l}\text { Circular economy design; new business } \\
\text { models; reverse cycles. }\end{array}$ & $\begin{array}{l}\text { Government policies; } \\
\text { collaboration between } \\
\text { players; incentives to players in } \\
\text { the supply chain to adopt } \\
\text { circular. } \\
\text { economy practices (E). }\end{array}$ \\
\hline
\end{tabular}


Table 2. Cont

\begin{tabular}{|c|c|c|c|c|}
\hline Authors & Denomination & Definition & Configurations (C) or indicators (I) tools & Enablers (E) or Inhibitors (I) \\
\hline Niu et al. (2019) [92] & $\begin{array}{l}\text { Design for } \\
\text { remanufacture } \\
\text { (DfRem)-driven } \\
\text { closed-loop } \\
\text { supply chain }\end{array}$ & $\begin{array}{l}\text { It affects both the manufacturing process of the initial product } \\
\text { and the recycling and remanufacturing processes of subsequent } \\
\text { waste products. }\end{array}$ & $\begin{array}{l}\text { Design for remanufacture (DfRem)-driven } \\
\text { two-stage; and multi-period modeling } \\
\text { processes (C). }\end{array}$ & Industry $4.0(\mathrm{E})$. \\
\hline $\begin{array}{l}\text { Taghikhah et al. } \\
\text { (2019) [55] }\end{array}$ & $\begin{array}{l}\text { Extended sustainable } \\
\text { supply chain (ESSC) }\end{array}$ & $\begin{array}{l}\text { The ESSC framework assumes that other managerial techniques } \\
\text { should also be employed, with a focus on the social dimension, } \\
\text { on education, motivation, nudging, and persuasion as part of } \\
\text { development towards sustainability. }\end{array}$ & $\begin{array}{c}\text { Green consumers behavior-environmental } \\
\text { behavior factors; and strategies for behavior } \\
\text { change (C). }\end{array}$ & N.A. \\
\hline $\begin{array}{c}\text { Zhang et al. (2019) } \\
\text { [82] }\end{array}$ & Circular supply chain & $\begin{array}{l}\text { A transition to CE requires a paradigm shift to an innovative } \\
\text { and more sustainable supply chain ecosystem. }\end{array}$ & $\begin{array}{l}\text { Smart waste management, and smart } \\
\text { enabling technologies. }\end{array}$ & $\begin{array}{l}\text { The lack of regulatory pressures, } \\
\text { the lack of environmental } \\
\text { education and culture of } \\
\text { environmental protection; and } \\
\text { the lack of market pressures and } \\
\text { demands (I). }\end{array}$ \\
\hline Zhu et al. (2019) [88] & $\begin{array}{l}\text { Closed-loop supply } \\
\text { chain }\end{array}$ & $\begin{array}{l}\text { It enables waste products to be professionally restored to the } \\
\text { same quality and performance } \\
\text { as new products and is considered to be the most valuable } \\
\text { product recycling method. }\end{array}$ & Decentralized or centralized decision system (C). & Warranty services (E). \\
\hline $\begin{array}{l}\text { Govindan et al. } \\
\text { (2020) [62] }\end{array}$ & $\begin{array}{l}\text { Circular closed-loop } \\
\text { supply chain }\end{array}$ & $\begin{array}{l}\text { Incorporating circular economy }(\mathrm{CE}) \text { into their supply chain } \\
\text { network to extend the sustainability frontier by reducing the } \\
\text { need for virgin materials, which contributes to the circulation } \\
\text { of resources. }\end{array}$ & $\begin{array}{l}\text { Supplier selection; and supply chain } \\
\text { network design. }\end{array}$ & Decision-making methods (E). \\
\hline $\begin{array}{l}\text { Hussain and Malik } \\
\text { (2020) [56] }\end{array}$ & Circular supply chain & $\begin{array}{l}\text { The future high performing state given the CE's established } \\
\text { links with strong sustainability. }\end{array}$ & N.A. & $\begin{array}{l}\text { Collaboration within supply } \\
\text { chain network; and supply chain } \\
\text { configuration (E). }\end{array}$ \\
\hline $\begin{array}{l}\text { Singhal, et al. (2020) } \\
\text { [90] }\end{array}$ & $\begin{array}{l}\text { Circular supply chain } \\
\text { (CSC) }\end{array}$ & $\begin{array}{l}\text { CSC helps organizations in making efficient use of resources } \\
\text { and results in increased value to the society. }\end{array}$ & $\begin{array}{l}\text { Design for remanufacturing; management } \\
\text { prescience; collection strategy; and purchase } \\
\text { intention (C). }\end{array}$ & N.A. \\
\hline
\end{tabular}




\section{Discussion and Conclusions}

The current competitive environment requires companies to be innovative in their production systems and to rethink the current use of resources and waste management. Circular productive systems must produce higher yields by using fewer resources, but also entail fewer emissions [106]. This circularity also extends to companies' supply chains, because of the key role it plays in their performance. Therefore, the adaptation of supply chains to the paradigm of the circular economy is attracting the interest of researchers. Based on a systematic review of the literature, a conceptual model has been proposed that includes the main dimensions for the development and implementation of circular supply chains.

\subsection{Theoretical Contribution}

Although there is increased interest from researchers since 2017, there is significant conceptual confusion. The use of terms that do not have the same meaning makes it difficult to establish a conceptual framework. These terms have been the basis for the establishment of the circular supply chain, but this term is a further step in the application of sustainability in supply chains.

There is a lack of theoretical basis from the perspective of business management or social aspects, since research has mainly focused on production and operations [31]. For all these reasons, it is interesting to apply certain theories from the field of strategic management-resource-based view, industrial ecology, agency theory, strategic networks, and institutional theory-in order to convert the circular supply chain into a favorable instrument that allows managing its resources and strategic capacities as well as its influence on the creation and maintenance of competitive advantages.

\subsection{Practical Contribution}

Providing action guidance to companies would promote success in incorporating the circular philosophy into supply chain systems, both intra-company and beyond company boundaries. The proposed model explores the impact of certain variables on the functioning and performance of circular supply chain operations. In order to facilitate decision-making, these variables have been classified into fundamental dimensions based on strategic management. Four dimensions have been identified to support the development of these new supply chains: (1) greater intensity in the relationships established in the supply chain, (2) adaptation of logistics and organizational, (3) disruptive and smart technologies, and (4) a functioning environment.

Regarding the establishment of a new framework of relationships (Proposition 1), successful circularization will require integrated synergistic actions by all actors and sectors involved and supported by improved flows of knowledge [107]. The development of a relational capacity is also essential. Relationships are closer, more frequent, and with new actors. Therefore, new rules of the game must be established that take into account the particularities of this new paradigm. Achieving a model of adoption of the full circular would imply its application both internally and externally, involving suppliers and customers in their internal activities [28].

In addition, the company needs to adapt both logistically and organizationally (Proposition 2). Reverse logistics encourage the return of material via the producer and industrial symbiosis favors the exchange of waste between industrial partners. But the transformation goes much further. It requires the design of circular business models [108]. Circular business models are a more complex and narrow type of business model innovation than sustainable business model, since the latter not only create sustainable value, but also involve dynamic management of the loops of resources. Consequently, achieving archetypes through business models of $\mathrm{CE}$, which are recognized at both the meso and micro levels, would allow the development of a common framework [96].

The new technologies allow the development of new functionalities necessary for productive and management change [58]. The main role of information and communication technologies is the application of push and saving impacts to optimize the economic processes of production, consumption 
and circulation. So, technology development toward a circular economy in three fundamental aspects (Proposition 3): (1) The production, for example recycling of waste, high-efficiency incinerators and cogeneration systems, product design, manufacturing, and remanufacturing processes; (2) the stakeholders, for example predictive analysis and the exchange of information; and (3) the information, so through the Internet of Things $(\mathrm{IO})$ and the Internet of services, information is monitored, controlled, and transferred.

As a final point, the environmental dimensions, whose relationship to the circular supply chain has been established in the Proposition 4. Through long-term agreements [15], the establishment of reward systems [58], and the achievement of financial and legal commitments [109], the company can capture value. Because of the need for collaboration between different actors, there is a need to employ a multidisciplinary system in solving problems where actors can be held responsible for others for their tasks and deliveries [83]. A holistic framework helps companies ensure they are more environmentally-conscious in circular supply chain activities and provides a roadmap in terms of environmental, economic, logistical, operational, and organizational activities [16] to adopt circular supply models effectively. The new framework is also more complex, and thus more difficult to apply than the original one.

\subsection{Limitations and Directions of Future Research}

This literature review has some limitations. Further research is needed to determine the applicability of these insights, since the greater weight in the analyzed articles has a marked theoretical or case study character. The second limitation is related to the search phase, where we limit our search to articles published in the selected journals, and skip other journals. We have only reviewed publications in English, so research published in other languages has not been analyzed in this study. Thirdly, as mentioned in this paper, there is a need to look more deeply, not only at the direct relationship between the dimensions and the CSC, but also at the moderating effects that the dimensions have on the relationships of the other dimensions to the results.

Finally, this paper presents a proposal when designing circular supply chains, however this proposal needs to be tested in different scenarios. Circular economy models, although popular, have not been fully tested [110]. The ability to fully map the relationships between the different dimensions and their effects on the performance of the circular supply chain will be of great interest in making practical recommendations for obtaining the highest possible return on investment.

Author Contributions: Conceptualization, R.G.-S. and D.S.-B.; data curation, A.M.F.; formal analysis, R.G.-S. and F.E.G.-M.; investigation, D.S.-B.; methodology, A.M.F.; project administration, F.E.G.-M.; supervision, F.E.G.-M.; writing-original draft preparation, R.G.-S.; writing—review and editing, R.G.-S. and F.E.G.-M. All authors have read and agreed to the published version of the manuscript.

Funding: This research was funded by the European Union under the LIFE Program, grant number: LIFE16 ENV/IT/000307 (LIFE Force of the Future).

Acknowledgments: The authors would like to acknowledge the editor and the two anonymous reviewers for their helpful suggestions to improve the paper.

Conflicts of Interest: The authors declare no conflict of interest.

\section{References}

1. Theophilus, O.; Dulebenets, M.A.; Pasha, J.; Abioye, O.F.; Kavoosi, M. Truck Scheduling at Cross-Docking Terminals: A Follow-Up State-Of-The-Art Review. Sustainability 2019, 11, 5245. [CrossRef]

2. Masoumi, S.M.; Kazemi, N.; Abdul-Rashid, S.H. Sustainable Supply Chain Management in the Automotive Industry: A Process-Oriented Review. Sustainability 2019, 11, 3945. [CrossRef]

3. Dulebenets, M.A. A Diploid Evolutionary Algorithm for Sustainable Truck Scheduling at a Cross-Docking Facility. Sustainability 2018, 10, 1333. [CrossRef]

4. Dong, C.; Li, Q.; Shen, B.; Tong, X. Sustainability in Supply Chains with Behavioral Concerns. Sustainability 2019, 11, 4051. [CrossRef] 
5. D'Adamo, I.; Gastaldi, M.; Rosa, P. Recycling of end-of-life vehicles: Assessing trends and performances in Europe. Technol. Forecast. Soc. Chang. 2020, 152, 119887. [CrossRef]

6. Guo, F.; Liu, Q.; Liu, D.; Guo, Z. On Production and Green Transportation Coordination in a Sustainable Global Supply Chain. Sustainability 2017, 9, 2071. [CrossRef]

7. Zhu, L.; Ren, X.; Lee, C.; Zhang, Y. Coordination Contracts in a Dual-Channel Supply Chain with a Risk-Averse Retailer. Sustainability 2017, 9, 2148. [CrossRef]

8. Kazancoglu, Y.; Kazancoglu, I.; Sagnak, M. A new holistic conceptual framework for green supply chain management performance assessment based on circular economy. J. Clean. Prod. 2018, 36, 82-1299. [CrossRef]

9. Beu, D.; Ciugudeanu, C.; Buzdugan, M. Circular Economy Aspects Regarding LED Lighting Retrofit-From Case Studies to Vision. Sustainability 2018, 10, 3674. [CrossRef]

10. Blomsma, F.; Brennan, G. The Emergence of Circular Economy: A New Framing Around Prolonging Resource Productivity. J. Ind. Ecol. 2017, 21, 603-614. [CrossRef]

11. Siyambalapitiya, J.; Zhang, X.; Liu, X. Is Governmentality the Missing Link for Greening the Economic Growth? Sustainability 2018, 10, 4204. [CrossRef]

12. Veleva, V.; Bodkin, G. Corporate-entrepreneur collaborations to advance a circular economy. J. Clean. Prod. 2018, 188, 20-37. [CrossRef]

13. Mont, O. Innovative approaches to optimising design and use of durable consumer goods. Int. J. Prod. Dev. 2008, 6, 227-250. [CrossRef]

14. McDonough, W.; Braungart, M. Cradle to Cradle: Remaking the Way We Make Things; North Point Press: New York, NY, USA, 2002.

15. Korhonen, J.; Nuur, C.; Feldmann, A.; Birkie, S.E. Circular economy as an essentially contested concept. J. Clean. Prod. 2018, 175, 544-552. [CrossRef]

16. Merli, R.; Preziosi, M.; Acampora, A. How do scholars approach the circular economy? A systematic literature review. J. Clean. Prod. 2018, 178, 703-722. [CrossRef]

17. Núñez-Cacho, P.; Molina-Moreno, V.; Corpas-Iglesias, F.A.; Cortés-García, F.J. Family Businesses Transitioning to a Circular Economy Model: The Case of "Mercadona". Sustainability 2018, 10, 538. [CrossRef]

18. Martinho, F.C.G.; Picado-Santos, L.G.; Capitão, S.D. Feasibility Assessment of the Use of Recycled Aggregates for Asphalt Mixtures. Sustainability 2018, 10, 1737. [CrossRef]

19. Mangla, S.; Luthra, S.; Mishra, N.; Singh, A.; Rana, N.; Dora, M.; Dwivedi, Y. Barriers to effective circular supply chain management in a developing country context. Prod. Plan. Control 2018, 29, 551-569. [CrossRef]

20. Bocken, N.M.P.; de Pau, I.; Bakker, C.; van der Grinten, B. Product design and business model strategies for a circular economy. J. Ind. Prod. Eng. 2016, 33, 308-320. [CrossRef]

21. Mehr, J.; Jedelhauser, M.; Binder, C.R. Transition of the Swiss Phosphorus System towards a Circular Economy_Part 1: Current State and Historical Developments. Sustainability 2018, 10, 1479. [CrossRef]

22. Sinclair, M.; Sheldrick, L.; Moreno, M.; Dewberry, E. Consumer Intervention Mapping-A Tool for Designing Future Product Strategies within Circular Product Service Systems. Sustainability 2018, 10, 2088. [CrossRef]

23. Chu, S.H.; Yang, H.; Lee, M.; Park, S. The Impact of Institutional Pressures on Green Supply Chain Management and Firm Performance: Top Management Roles and Social Capital. Sustainability 2017, 9, 764. [CrossRef]

24. Akinade, O.O.; Oyedele, L.O. Integrating construction supply chains within a circular economy: An ANFIS-based waste analytics system (A-WAS). J. Clean. Prod. 2019, 229, 863-873. [CrossRef]

25. Guide, V.D.R.; Harrison, T.P.; Van Wassenhove, L.N. The Challenge of Closed-Loop Supply Chains. Interfaces 2003, 33, 3-6. [CrossRef]

26. Masi, D.; Day, S.; Godsell, J. Supply chain configurations in the Circular Economy: A systematic literature review. Sustainability 2017, 9, 1602. [CrossRef]

27. Farooque, M.; Zhang, A.; Thürer, M.S.; Qu, T.; Huisingh, D. Circular supply chain management: A definition and structured literature review. J. Clean. Prod. 2019, 228, 882-900. [CrossRef]

28. Homrich, A.S.; Galvao, G.; Abadia, L.G.; Carvalho, M.M. The circular economy umbrella: Trends and gaps on integrating pathways. J. Clean. Prod. 2018, 175, 525-543. [CrossRef]

29. Rosa, P.; Sassanelli, C.; Terzi, S. Towards Circular Business Models: A systematic literature review on classification frameworks and archetypes. J. Clean. Prod. 2019, 236, 117696. [CrossRef]

30. Geissdoerfer, M.; Savaget, P.; Bocken, N.M.P.P.; Hultink, E.J. The Circular Economy-A new sustainability paradigm? J. Clean. Prod. 2017, 143, 757-768. [CrossRef] 
31. Lahti, T.; Wincent, J.; Parida, V. A Definition and Theoretical Review of the Circular Economy, Value Creation, and Sustainable Business Models: Where Are We Now and Where Should Research Move in the Future? Sustainability 2018, 10, 2799. [CrossRef]

32. Reichertz, J. Abduction: The logic of discovery of grounded theory. Forum Qual. Soz. 2009, 11, 1-16.

33. Kitchenham, B. Procedures for Performing Systematic Reviews, TR/SE-0401; Keele University: Keele, UK, 2004.

34. Kalmykova, Y.; Sadagopanb, M.; Rosado, L. Circular economy-From review of theories and practices to development of implementation tools. Resour. Conserv. Recycl. 2018, 135, 190-201. [CrossRef]

35. Ferreira Gregorio, V.; Pié, L.; Terceño, A. A Systematic Literature Review of Bio, Green and Circular Economy Trends in Publications in the Field of Economics and Business Management. Sustainability 2018, 10, 4232. [CrossRef]

36. Ghisellini, P.; Cialani, C.; Ulgiati, S. A review on circular economy: The expected transition to a balanced interplay of environmental and economic systems. J. Clean. Prod. 2016, 114, 11-32. [CrossRef]

37. Pearce, D.; Turner, R.K. Economics of Natural Resources and the Environment; Johns Hopkins University Press: Baltimore, MD, USA, 1990.

38. Kirchherr, J.; Reike, D.; Hekkert, M. Conceptualizing the circular economy: An analysis of 114 definitions. Resour. Conserv. Recycl. 2017, 127, 221-232. [CrossRef]

39. Avdiushchenko, A. Toward a Circular Economy Regional Monitoring Framework for European Regions: Conceptual Approach. Sustainability 2018, 10, 4398. [CrossRef]

40. Van Buren, N.; Demmers, M.; van der Heijden, R.; Witlox, F. Towards a Circular Economy: The Role of Dutch Logistics Industries and Governments. Sustainability 2016, 8, 647. [CrossRef]

41. De Angelis, R.; Howard, M.; Miemczyk, J. Supply Chain Management and the Circular Economy: Towards the Circular Supply Chain. Prod. Plan. Control 2017, 29, 425-437. [CrossRef]

42. Liu, L.; Liang, Y.; Song, Q.; Li, J. A review of waste prevention through 3R under the concept of circular economy in China. J. Mater. Cycles Waste 2017, 7, 1-10. [CrossRef]

43. de Mattos, C.A.; de Albuquerque, T.L.M. Enabling Factors and Strategies for the Transition Toward a Circular Economy (CE). Sustainability 2018, 10, 4628. [CrossRef]

44. Fonseca, L.; Domingues, J.; Pereira, M.; Martins, F.; Zimon, D.; Fonseca, L.M.; Domingues, J.P.; Pereira, M.T.; Martins, F.F.; Zimon, D. Assessment of Circular Economy within Portuguese Organizations. Sustainability 2018, 10, 2521. [CrossRef]

45. Lewandowski, M. Designing the business models for circular economy-Towards the conceptual framework. Sustainability 2016, 8, 43. [CrossRef]

46. Molina-Moreno, V.; Leyva-Díaz, J.C.; Sánchez-Molina, J.; Peña-García, A. Proposal to Foster Sustainability through Circular Economy-Based Engineering: A Profitable Chain from Waste Management to Tunnel Lighting. Sustainability 2017, 9, 2229. [CrossRef]

47. Oncioiu, I.; Căpuşneanu, S.; Türkeș, M.C.; Topor, D.I.; Oprea Constantin, D.-M.; Marin-Pantelescu, A.; Hint, M.S. The Sustainability of Romanian SMEs and Their Involvement in the Circular Economy. Sustainability 2018, 10, 2761. [CrossRef]

48. Zambon, I.; Colantoni, A.; Cecchini, M.; Mosconi, E.M. Rethinking Sustainability within the Viticulture Realities Integrating Economy, Landscape and Energy. Sustainability 2018, 10, 320. [CrossRef]

49. Nußholz, J.L.K.; Rasmussen, F.N.; Milios, L. Circular building materials: Carbon saving potential and the role of business model innovation and public policy. Resour. Conserv. Recycl. 2019, 141, 308-316. [CrossRef]

50. Muñoz-Torres, M.J.; Fernández-Izquierdo, M.Á.; Rivera-Lirio, J.M.; Ferrero-Ferrero, I.; Escrig-Olmedo, E.; Gisbert-Navarro, J.V.; Marullo, M.C. An Assessment Tool to Integrate Sustainability Principles into the Global Supply Chain. Sustainability 2018, 10, 535. [CrossRef]

51. Masi, D.; Kumar, V.; Garza-Reyes, J.A.; Godsell, J. Towards a more circular economy: Exploring the awareness, practices, and barriers from a focal firm perspective. Prod. Plan. Control 2018, 29, 539-550. [CrossRef]

52. Genovese, A.; Acquaye, A.A.; Figueroa, A.; Koh, S.L. Sustainable supply chain management and the transition towards a circular economy: Evidence and some applications. Omega 2017, 66, 344-357. [CrossRef]

53. Daú, G.; Scavarda, A.; Scavarda, L.F.; Portugal, V.J.T. The Healthcare Sustainable Supply Chain 4.0: The Circular Economy Transition Conceptual Framework with the Corporate Social Responsibility Mirror. Sustainability 2019, 11, 3259. [CrossRef]

54. French, M.L.; LaForge, R.L. Closed-loop supply chains in process industries: An empirical study of producer re-use issues. J. Oper. Manag. 2006, 24, 271-286. [CrossRef] 
55. Taghikhah, F.; Voinov, A.; Shukla, N. Extending the supply chain to address sustainability. J. Clean. Prod. 2019, 229, 652-666. [CrossRef]

56. Hussain, M.; Malik, M. Organizational enablers for circular economy in the context of sustainable supply chain management. J. Clean. Prod. 2020, 256, 120375. [CrossRef]

57. Su, B.W.; Heshmati, A.; Geng, Y.; Yu, X.M. A review of the circular economy in China: Moving from rhetoric to implementation. J. Clean. Prod. 2013, 42, 215-227. [CrossRef]

58. Coenen, J.; van der Heijden, R.; van Riel, A.C.R. Making a Transition toward more Mature Closed-Loop Supply Chain Management under Deep Uncertainty and Dynamic Complexity: A Methodology. Sustainability 2019, 11, 2318. [CrossRef]

59. Denyer, D.; Tranfield, D. Producing a systematic review. In The Sage Handbook of Organizational Research Methods; Buchanan, D.A., Bryman, A., Eds.; Sage Publications Ltd.: Thousand Oaks, CA, USA, 2009; pp. 671-689.

60. Geissdoerfer, M.; Morioka, S.M.; de Carvalho, M.M.; Evans, S. Business models and supply chains for the circular economy. J. Clean. Prod. 2018, 190, 712-721. [CrossRef]

61. Weetman, C. A Circular Economy Handbook for Business and Supply Chains: Repair, Remake, Redesign, Rethink; Kogan Page: London, UK, 2017.

62. Govindan, K.; Mina, H.; Esmaeili, A.; Gholami-Zanjani, S.M. An Integrated Hybrid Approach for Circular supplier selection and Closed loop Supply Chain Network Design under Uncertainty. J. Clean. Prod. 2020, 242, 118317. [CrossRef]

63. Wernerfelt, B. A resource-based view of the firm. Strateg. Manag. J. 1984, 5, 171-180. [CrossRef]

64. Barney, J. Firm resources and sustained competitive advantage. J. Manag. 1991, 17, 99-120. [CrossRef]

65. Grant, R.M. The Resource-Based Theory of competitive advantage: Implications for strategy formulation. Calif. Manag. Rev. 1991, 34, 114-135. [CrossRef]

66. Mousavi, S.; Bossink, B.; van Vliet, M. Dynamic capabilities and organizational routines for managing innovation towards sustainability. J. Clean. Prod. 2018, 203, 224-239. [CrossRef]

67. Teece, D.J. Explicating dynamic capabilities: The nature and microfoundations of (sustainable) enterprise performance. Strateg. Manag. J. 2007, 28, 1319-1350. [CrossRef]

68. Teece, D.J. Dynamic Capabilities: Routines versus Entrepreneurial Action. J. Manag. Stud. 2012, 49, $1395-1401$. [CrossRef]

69. Portillo-Tarragona, P.; Scarpellini, S.; Moneva, J.M.; Valero-Gil, J.; Aranda-Usón, A. Classification and Measurement of the Firms' Resources and Capabilities Applied to Eco-Innovation Projects from a Resource-Based View Perspective. Sustainability 2018, 10, 3161. [CrossRef]

70. Ranta, V.; Aarikka-Stenroos, L.; Mäkinen, S.J. Creating value in the circular economy: A structured multiple-case analysis of business models. J. Clean. Prod. 2018, 201, 988-1000. [CrossRef]

71. Laurenti, R.; Singh, J.; Frostell, B.; Sinha, R.; Binder, C.R. The Socio-Economic Embeddedness of the Circular Economy: An Integrative Framework. Sustainability 2018, 10, 2129. [CrossRef]

72. Sumter, D.; Bakker, C.; Balkenende, R. The Role of Product Design in Creating Circular Business Models: A Case Study on the Lease and Refurbishment of Baby Strollers. Sustainability 2018, 10, 2415. [CrossRef]

73. Matos, S.; Silvestre, B. Managing stakeholder relations when developing sustainable business models: The case of the Brazilian energy sector. J. Clean. Prod. 2013, 45, 61-73. [CrossRef]

74. Laubscher, M.; Marinelli, T. Integration of circular economy in business. In Proceedings of the Conference; Going Green-Care Innovation 2014, Vienna, Austria, 17-20 November 2014.

75. Lüdeke-Freund, F.; Gold, S.; Bocken, N. A Review and Typology of Circular Economy Business Model Patterns. J. Ind. Ecol. 2018, 23, 36-61. [CrossRef]

76. Gulati, R.; Nitin, N.; Zaheer, A. Strategic Networks. Strateg. Manag. J. 2000, 21, 203-215. [CrossRef]

77. Freeman, L.C. Centrality in Social Networks Conceptual Clarification. Soc. Netw. 1979, 1, 215-239. [CrossRef]

78. Kogut, B. The network as knowledge: Generative rules and the emergence of structure. Strateg. Manag. J. 2000, 21, 405-425. [CrossRef]

79. Brown, P.; Bocken, N.; Balkenende, R. Why Do Companies Pursue Collaborative Circular Oriented Innovation? Sustainability 2019, 11, 635. [CrossRef]

80. Meherishi, L.; Narayana, S.A.; Ranjani, K.S. Sustainable packaging for supply chain management in the circular economy: A review. J. Clean. Prod. 2019, 237, 117582. [CrossRef] 
81. Albuquerque, T.L.M.; Mattos, C.A.; Scur, G.; Kissimoto, K. Life cycle costing and externalities to analyze circular economy strategy: Comparison between aluminum packaging and tinplate. J. Clean. Prod. 2019, 234, 477-486. [CrossRef]

82. Zhang, A.; Venkatesh, V.G.; Liu, Y.; Wan, M.; Qu, T.; Huisingh, D. Barriers to smart waste management for a circular economy in China. J. Clean. Prod. 2019, 240, 118198. [CrossRef]

83. Leising, E.; Quist, J.; Bocken, N. Circular Economy in the building sector: Three cases and a collaboration tool. J. Clean. Prod. 2018, 176, 976-989. [CrossRef]

84. Salim, H.; Stewart, R.A.; Sahin, O.; Dudley, M. Drivers, barriers and enablers to end-of-life management of solarphotovoltaic and battery energy storage systems: A systematic literature review. J. Clean. Prod. 2019, 211, 537-554. [CrossRef]

85. Zeng, H.; Chen, X.; Xiao, X.; Zhou, Z. Institutional pressures, sustainable supply chain management, and circular economy capability: Empirical evidence from Chinese eco-industrial park firms. J. Clean. Prod. 2017, 155, 54-65. [CrossRef]

86. Prosman, E.J.; Sacchi, R. New environmental supplier selection criteria for circular supply chains: Lessons from a consequential LCA study on waste recovery. J. Clean. Prod. 2018, 172, 2782-2792. [CrossRef]

87. Borrello, M.; Caracciolo, F.; Lombardi, A.; Pascucci, S.; Cembalo, L. Consumers' Perspective on Circular Economy Strategy for Reducing Food Waste. Sustainability 2017, 9, 141. [CrossRef]

88. Zhu, X.; Yu, L.; Li, W. Warranty Period Decision and Coordination in Closed-Loop Supply Chains Considering Remanufacturing and Consumer Behavior. Sustainability 2019, 11, 4237. [CrossRef]

89. de Oliveira, C.T.; Luna, M.M.M.; Campos, L.M.S. Understanding the Brazilian expanded polystyrene supply chain and its reverse logistics towards circular economy. J. Clean. Prod. 2019, 235, 562-573. [CrossRef]

90. Singhal, D.; Tripathya, S.; Jena, S.K. Remanufacturing for the circular economy: Study and evaluation of critical factors. Resour. Conserv. Recycl. 2020, 156, 104681. [CrossRef]

91. Duan, C.; Xiu, G.; Yao, F. Multi-Period E-Closed-Loop Supply Chain Network Considering Consumers' Preference for Products and AI-Push. Sustainability 2019, 11, 4571. [CrossRef]

92. Niu, S.H.; Zhuo, H.; Xue, K. DfRem-Driven Closed-Loop Supply Chain Decision-Making: A Systematic Framework for Modeling Research. Sustainability 2019, 11, 3299. [CrossRef]

93. Guarnieria, P.; Cerqueira-Streita, J.A.; Batista, L.C. Reverse logistics and the sectoral agreement of packaging industry in Braziltowards a transition to circular economy. Resour. Conserv. Recycl. 2020, 152, 104541. [CrossRef]

94. Subramoniam, R.; Huisingh, D.; Babu, R. Remanufacturing for the automotive aftermarket-strategic factors: Literature review and future research needs. J. Clean. Prod. 2009, 17, 1163-1174. [CrossRef]

95. Emmanuel-Ebikake, O.; Sassanelli, C.; Terzi, S. PSS design through Design for Supply Chain: State of the art review. In Proceedings of the 28th CIRP Design Conference, Nantes, France, 23-25 May 2018.

96. Oghazi, P.; Mostaghel, R. Circular Business Model Challenges and Lessons Learned-An Industrial Perspective. Sustainability 2018, 10, 739. [CrossRef]

97. Maaß, O.; Grundmannm, P.H. Governing Transactions and Interdependences between inked Value Chains in a Circular Economy: The Case ofWastewater Reuse in Braunschweig (Germany). Sustainability 2018, 10, 1125. [CrossRef]

98. Mishra, J.L.; Hopkinson, P.G.; Tidridge, G. Value creation from circular economy-led closed loop supply chains: A case study of fast-moving consumer goods. Prod. Plan. Control 2018, 29, 509-521. [CrossRef]

99. Yang, M.; Smart, P.; Kumar, M.; Jolly, M.; Evans, S. Product-service systems business models for circular supply chains. Prod. Plan. Control 2018, 29, 498-508. [CrossRef]

100. Sassanelli, C.; Rossi, M.; Pezzotta, G.; Pacheco, D.J.P.; Terzi, S. Defining lean product service systems features and research trends through a systematic literature review. Int. J. Prod. Lifecycle Manag. 2019, 12, 37-61. [CrossRef]

101. Ali, S.H. Social and Environmental Impact of the Rare Earth Industries. Resources 2014, 3, 123-134. [CrossRef]

102. Nascimento, D.L.M.; Alencastro, V.; Quelhas, O.L.G.; Caiado, R.G.G.; Garza-Reyes, J.A.; Tortorella, G.L. Exploring Industry 4.0 technologies to enable circular economy practices in a manufacturing context: A business model proposal. J. Manuf. Technol. Manag. 2018, 30, 607-627. [CrossRef]

103. Dubey, R.; Gunasekaran, A.; Childe, S.J.; Papadopoulos, T.; Luo, Z.; Wamba, S.F.; Roubaud, D. Can Big Data and Predictive Analytics Improve Social and Environmental Sustainability? Technol. Forecast. Soc. Chang. 2017, 144, 534-545. [CrossRef] 
104. Liang, S.; Feng, Y.; Xu, M. Structure of the Global Virtual Carbon Network: Revealing Important Sectors and Communities for Emission Reduction. J. Ind. Ecol. 2015, 19, 307-320. [CrossRef]

105. Vlajic, J.V.; Mijailovic, R.; Bogdanova, M. Creating loops with value recovery: Empirical study of fresh food supply chains. Prod. Plan. Control 2018, 29, 522-538. [CrossRef]

106. Strauch, S.M.; Wenzel, L.C.; Bischoff, A.; Dellwig, O.; Klein, J.; Schüch, A.; Wasenitz, B.; Palm, H.W. Commercial African Catfish (Clarias gariepinus) Recirculating Aquaculture Systems: Assessment of Element and Energy Pathways with Special Focus on the Phosphorus Cycle. Sustainability 2018, 10, 1805. [CrossRef]

107. Withers, P.J.A.; Doody, D.G.; Sylvester-Bradle, R. Achieving Sustainable Phosphorus Use in Food Systems through Circularisation. Sustainability 2018, 10, 1804. [CrossRef]

108. Braun, A.; Kleine-Moellhoff, P.; Reichenberger, V.; Seiter, S.T. Case Study Analysing Potentials to Improve Material Efficiency in Manufacturing Supply Chains, Considering Circular Economy Aspects. Sustainability 2018, 10, 880. [CrossRef]

109. Bocken, N.; Short, S.; Rana, P.; Evans, S. A literature and practice review to develop Sustainable Business Model Archetypes. J. Clean. Prod. 2014, 65, 42-45. [CrossRef]

110. D'Adamo, I.; Falcone, P.M.; Ferella, F. A Socio-Economic Analysis of Biomethane in the Transport Sector: The Case of Italy. Waste Manag. 2019, 95, 102-115. [CrossRef]

(C) 2020 by the authors. Licensee MDPI, Basel, Switzerland. This article is an open access article distributed under the terms and conditions of the Creative Commons Attribution (CC BY) license (http://creativecommons.org/licenses/by/4.0/). 